\title{
DEBIUTY
}

Marta Janocha

marta.janocha@ukw.edu.pl

Uniwersytet Kazimierza Wielkiego w Bydgoszczy

Instytut Prawa, Administracji i Zarządzania

ul. M.K. Ogińskiego 16

85-092 Bydgoszcz

\section{Mistrz i uczniowie. Rola sygnatur w badaniach oryginalności dzieł Rembrandta}

\author{
Master and students. The role of signatures \\ in research of originality of Rembrandt's works
}

Summary: The purpose of this paper is to show the role of signature expertise in the process of attribution or acknowledgement of the authenticity of a painting, based on the example of Rembrandt van Rijn's works. Results of various analyses aimed at establishing the attribution of a work to an author may not, if examined separately, produce satisfactory outcomes. Only their application in combination may lead to a conviction about the authenticity of a work. Examination of the authenticity of signatures has made it possible to distinguish between paintings of Rembrandt from his contemporary copies and later forgeries. Experts from the Rembrandt Research Project analyzed signatures in terms of their accordance with the master's life period and the similarities in the construction of signs. Furthermore, they searched for symptoms of interference with a signature. The presence of Rembrandt's authentic signature on a painting limits the number of potential authors of the work to the circle of the master himself or his students. Thus additionally an expert should take into consideration the fact that Rembrandt's signature may also appear on the work of one of his students.

Keywords: Rembrandt van Rijn, expertise, signature, attribution, authentication, handwriting expert, Rembrandt Research Project (RRP) 


\section{DEBIUTY}

Marta Janocha

Streszczenie: Celem artykułu jest ukazanie roli ekspertyz sygnatur w procesie ustalania atrybucji lub potwierdzania autentyczności obrazów na przykładzie dzieł Rembrandta van Rijn. Wyniki różnorodnych analiz, zmierzających do ustalenia atrybucji dzieła, rozpatrywane oddzielnie mogą nie dawać zadowalających rezultatów. Dopiero ich połączenie może prowadzić do uzyskania przekonania co do autentyczności dzieła. Badania autentyczności sygnatur przyczyniły się do odróżnienia twórczości Rembrandta od współczesnych mu kopii oraz późniejszych falsyfikatów. Eksperci z Rembrandt Research Project analizowali sygnatury pod kątem zgodności z okresem w twórczości mistrza, podobieństw w budowie znaków oraz poszukiwali symptomów ingerencji w sygnaturę. Należy zachować szczególną ostrożność przy określaniu pochodzenia dzieła, ponieważ podpis mistrza może widnieć również na pracach uczniów. Autentyczna sygnatura Rembrandta na obrazie ogranicza jednak grono potencjalnych autorów dzieła do kręgu uczniów lub samego mistrza.

Słowa kluczowe: Rembrandt van Rijn, sygnatura, Dziewczyna w kapeluszu, ekspertyza, atrybucja, autentyczność obrazów, pismoznawstwo, Rembrandt Research Project (RRP)

Dynamiczny rozwój rynku dzieł sztuki powoduje, że wzrasta popyt na opinie ekspertów dotyczące autentyczności dzieł. W literaturze nie brakuje opracowań na temat znanych fałszerzy, niektórzy z nich nawet udzielali publicznych wykładów (Tom Keating ${ }^{1}$ ). Mieczysław Morka ostrzega, że od XVII w. na rynku dzieł sztuki znajduje się ogromna liczba obrazów z nieautentycznymi sygnaturami ${ }^{2}$. Fałszowanie dzieł sztuki nie jest nowym zjawiskiem, jednak współcześnie nauka oferuje znacznie szerszy wachlarz narzędzi potwierdzania lub ustalania atrybucji dzieła niż kiedyś. Autentyczność dzieła sztuki można rzetelnie potwierdzić poprzez przeprowadzenie badań fizykochemicznych, analiz sygnatur, wykonanie ekspertyzy technologii i technik malarskich oraz wykorzystanie bogatej wiedzy na temat stylu konkretnego artysty ${ }^{3}$. Początkowo badaniem autentyczności obrazów zajmowali się wyłącznie historycy sztuki na podstawie wiedzy na temat twórczości artysty i własnego doświadczenia. Natomiast współcześnie do historyków sztuki i konserwatorów dołączyli specjaliści z innych dziedzin, w tym pismoznawcy. W niniejszej pracy przedstawiona zostanie rola analizy sygnatur w procesie ustalania autentyczności dzieł Rembrandta.

\footnotetext{
1 https://www.youtube.com/watch?v=4Y4GAq_hayY [dostęp: 5.09.2014].

2 M. Morka, Kilka uwag o wartości sygnatur i pisaniu ekspertyz, w: J. Miziołek, M. Morka (red.), Falsyfikaty dzieł sztuki w zbiorach polskich, Agencja Wydawniczo-Poligraficzna Agraf, Warszawa 2002, s. 251.

3 Ibidem, s. 267.
} 


\section{Życie Mistrza holenderskiego złotego wieku}

Rembrandt Hermenszon van Rijn urodził się w 1606 r. w Lejdzie ${ }^{4}$. Jest uznawany za jednego z najwybitniejszych malarzy holenderskiego złotego wieku. Rembrandt nie pochodził z rodziny artystów - był synem młynarza Harmena Gerritszona ${ }^{5}$. Przejawiał uzdolnienia artystyczne już jako nastolatek. W 1620 r. rozpoczął studia na uniwersytecie $w$ Lejdzie, jednak przerwał naukę, by przez 3 lata uczyć się podstaw malarstwa w pracowni Jacoba van Swanenburgha ${ }^{6}$. Od 1624 r. szlifował swój talent $w$ Amsterdamie pod okiem poważanego malarza dzieł historycznych - Pietera Lastmana ${ }^{7}$. Młody adept sztuki miał tam okazję zapoznać się z techniką słynnego Caravaggia ${ }^{8}$. Realizm włoskiego malarza miał ogromny wpływ na młodego Rembrandta\%. Mistrzowskie operowanie światłem i cieniem przez Rembrandta stanowi następstwo stylu włoskiego mistrza, którego obrazy, pogrążone w ciemności, oświetlone są pojedynczym źródłem światła (np. Zaśnięcie Marii) ${ }^{10}$. Po powrocie do Lejdy Rembrandt założył swoją pierwszą pracownię wspólnie z innym uczniem Lastmana - Janem Lievensem. W pracach z tego okresu widoczny jest wzajemny wpływ artystów ${ }^{11}$, np. w wyborze tematów dzieł (Święty Paweł J. Lievensa oraz Apostoł Pawet przy stole do pracy Rembrandta).

W 1631 r. holenderski mistrz przeniósł się do Amsterdamu i nawiązał współpracę z wpływowym marszandem Hendrickiem van Uylenburgh ${ }^{12}$. Rembrandt w jego pracowni malował portrety najbogatszych mieszkańców Amsterdamu. Kilka lat później poślubił siostrzenicę Hendricka van Uylenburgha - Saskię, którą często uwieczniał na płótnach ${ }^{13}$. W 1635 r. otworzył własną, dobrze prosperującą pracownię. Jednak był to dla mistrza także trudny okres. Między 1638 a 1642 r. zmarto troje z czworga dzieci Rembrandta oraz ukochana żona - Saskia ${ }^{14}$. Holenderski mistrz został sam z najmłodszym synem Tytusem. Później związał się z młodziut-

4 E. van de Wetering, Rembrandt van Rijn [hasło], w: Encyclopaedia Britannica, https://www.britannica. com/biography/Rembrandt-van-Rijn [dostęp:10.10.2016].

5 Ibidem.

6 E. Michel, Harmensz van Rijn Rembrandt, Parkstone International, New York 2011, s. 8.

7 S. Zuffi, Rembrandt, Rzeczpospolita, Warszawa 2006, s. 81.

8 E. Starcky, Rembrandt, przeł. A. Kaniewska, „Panda”, Warszawa 1996, s. 32.

9 R. Hughes, Really Rembrandt?, „Time” 1992, t. 139, nr 21, s. 2.

10 E. van de Wetering, op. cit.

11 E. van de Wetering, An illustrated chronological survey of Rembrandt's small-scale 'histories': paintings, etchings and a selection of drawings, w: A Corpus of Rembrandt Paintings, t. V: Small scale history paintings, Springer Netherlands, 2011, s. 161, http://www.rembrandtdatabase.org/Rembrandt/Content/pdfs/ CorpusRembrandt_5.pdf [dostęp: 20.10.2016].

12 E. Michel, op. cit., s. 9.

13 Ibidem.

14 Ibidem. 


\section{DEBIUTY}

Marta Janocha

ką Hendrickje Stoffels ${ }^{15}$. Coraz mniej czasu poświęcał na wykonanie zamówień. W 1656 r. ogłosił bankructwo, a zbiory jego dzieł zostały zlicytowane. W 1663 r. zmarła Hendrickje, a następnie syn mistrza - Tytus. Ostatnie lata Rembrandt spędził z Cornelią, córką ze związku z Hendrickje. Zmarł w Amsterdamie 4.10.1669 r. ${ }^{16}$

\section{Pracownia Rembrandta}

W pracowni mistrza młodzi adepci sztuki kopiowali obrazy, uzupełniali mniej istotne elementy lub na podstawie dzieł mistrza tworzyli własne, poszukując swojej artystycznej drogi. Była to wXVII w. powszechna praktyk $a^{17}$. W niektórych obrazach mistrz malował tylko najtrudniejszy element, pozostawiając resztę pracy młodym malarzom. Nie można dokładnie określić liczby uczniów Rembrandta, ponieważ nie prowadzono tego typu rejestrów. Jednak do najbardziej znanych należą: Govaert Flinck, Carel Fabritius, Arent de Gelder, Gerrit Dou, Samuel van Hoogstraten oraz Ferdinand Bol ${ }^{18}$. Bol, utalentowany malarz z Dordrechtu, dążył w swoich pracach do przedstawienia Rembrandtowskiej proporcji między światłem a cie$n_{\text {niem }}{ }^{19}$. Sposób rozłożenia światła w akwaforcie Święta Rodzina w ciemnej komnacie koresponduje z akwafortą Rembrandta Hieronim w ciemnej komnacie ${ }^{20}$. Uczniowie dążyli do przejęcia techniki mistrza tak bardzo, jak to tylko możliwe ${ }^{21}$. W obliczu talentu Rembrandta młodzi malarze musieli tworzyć w sposób podobny albo liczyć się z nieakceptowaniem swoich dzieł. Dlatego ekspertyza dzieł Rembrandta stanowi niełatwe zadanie, wymagające ogromnego doświadczenia oraz zasobu wiedzy z wielu dziedzin.

\section{Znaczenie sygnowania obrazów}

Podpisywanie obrazów łączono ze wzrostem społecznego prestiżu zawodu malarza oraz z poczuciem indy widualizmu twórcy ${ }^{22}$. Współcześnie sygnatura pełni ważną funkcję w określaniu atrybucji obrazu oraz stanowi środek wyrazu artystycznego, jednak należy pamiętać także o innym jej znaczeniu - w XVII w. był to znak ja-

\footnotetext{
15 S. Zuffi, op. cit., s. 81.

16 Ibidem, s. 82.

17 Ibidem.

18 E. Michel, op.cit., s. 14.

19 K. Zabulska, Ryciny ze zbiorów Muzeum Narodowego w Gdańsku, w: B. Purc-Stępniak, K. Zabuska, G. Zinówko (oprac.), Rembrandt i krąg jego tradycji, Muzeum Okręgowe im. Leona Wyczółkowskiego, Bydgoszcz 2010, s. 16-17.

20 Ibidem, s. 17.

21 E. van de Wetering, Connoisseurship and Rembrantd's paintings: new directions in the Rembrandt's Research Project, part II, „The Burlington Magazine” 2008, t. 150, nr 1259, s. 84.

22 M. Morka, op. cit., s. 252.
} 
Mistrz i uczniowie. Rola sygnatur w badaniach oryginalności... Master and students. The role of signatures in research of originality...

kości pracowni dawnego mistrza ${ }^{23}$. Opatrzenie dzieła podpisem mistrza oznaczało, że czeladnik wykonał swoją pracę zgodnie z wymogami pracowni ${ }^{24}$. Również Rembrandt stosował sygnaturę jako potwierdzenie dobrze wykonanej pracy czeladnika, jednak znacznie rzadziej niż inni malarze tego okresu25. Ze względu na identyfikacyjną rolę sygnatury, w późniejszych wiekach znacznie podnosiła ona wartość obrazu, dlatego setki obrazów zaopatrzono w „podpisy wielkich mistrzów”26. Już krótko po śmierci Rembrandta każdy, kto posiadał XVII-wieczny portret namalowany w odpowiedniej manierze, twierdził, że to dzieło holenderskiego mistrza ${ }^{27}$. Określenie autentyczności podpisu istotnie ułatwia więc ustalenie atrybucji dzieła, lecz nie powinno być jedynym narzędziem weryfikacji28.

\section{Metody weryfikacji autentyczności sygnatur}

Przy ustalaniu autentyczności sygnatury należy zwrócić uwagę na wiele różnych czynników. W celu ujawnienia symptomów podrabiania oraz przerabiania przeprowadza się analizę wstępną, czyli obserwację w świetle widzialnym, w tym monochromatycznym, wykorzystuje promieniowanie UV, podczerwień oraz prześwietlenia obrazu z użyciem promieni Roentgena ${ }^{29}$. Oryginalna sygnatura zostaje umieszczona na wciąż "mokrym” obrazie. Ostatnia warstwa dzieła nie jest jeszcze dobrze wyschnięta, dlatego świeża farba wykorzystana do naniesienia sygnatury ściśle łączy się z warstwą leżącą bezpośrednio pod nią. Brak tego subtelnego połączenia może sugerować, że sygnaturę dodano długo po ukończeniu dzieła. Aby to ustalić, można zastosować promieniowanie UV. Jeżeli podpis wyraźnie odznacza się od reszty obrazu, to znaczy, że został umieszczony na obrazie później ${ }^{30}$. Pokrycie całego obrazu grubą warstwą werniksu niweluje niestety ten efekt ${ }^{31}$, podobnie

23 P. Burke, Kultura i społeczeństwo w renesansowych Włoszech, przeł. K. Siewierski, Państwowy Instytut Wydawniczy, Warszawa 1991, s. 61.

24 Ibidem.

25 Na przykład w pracowni Rubensa liczni asystenci wykonywali określone części dzieła (tło, tkaniny). Więcej na ten temat: E. van de Wetering, More than one hand in paintings by Rembrandt, w: A Corpus..., t. V, s. 311-312.

26 T. Widła, Sygnatura w ekspertyzie pismoznawczej - pisarska ciagłość, „Człowiek i Dokumenty” 2014, t. 34 , s. 53.

27 R. Hughes, op. cit., s. 3.

28 M. Morka, op. cit., s. 262.

29 T. Widła, Metody ustalania autentyczności obrazów, „Studia Kryminologiczne, Kryminalistyczne, penitencjarne" 1979, t. 10, s. 275.

30 S. Zabłocka, Sygnatury, a autentyczność dzieła, 5.07.2012, http://rynekisztuka.pl/2012/07/05/ sygnatury-a-autentycznosc-dziela/ [dostęp: 6.09.2014].

31 D. Markowski, Ocena autentyczności dzieła na przykładzie wybranych obrazów polskiego malarstwa XIX i XX wieku, w: J. Flik (red.), Ars longa - Vita brevis. Tradycyjne i nowoczesne metody badania dzieł sztuki, Wydawnictwo Uniwersytetu Mikołaja Kopernika, Toruń 2003, s. 252. 


\section{DEBIUTY}

Marta Janocha

jak wprowadzenie do farb soli metali32. Jednak badanie przekroju stratygraficznego pozwala na określenie, w której warstwie obrazu znajduje się sygnatura ${ }^{33}$.

Badania pismoznawcze obejmują nie tylko techniczną, ale także graficzną, językową i treściową warstwę pisma ${ }^{34}$. Dawni mistrzowie sygnowali obrazy nie tylko imieniem lub nazwiskiem, ale również pseudonimami oraz piktograma$\mathrm{mi}$, czasami uzupełnionymi o informację na temat czasu lub miejsca powstania dzieła ${ }^{35}$. Możliwość analizowania treści oraz warstwy językowej jest ograniczona, dlatego badania koncentrują się na warstwie graficznejej. Między podpisami składanymi na klasycznych dokumentach a sygnaturami występują istotne różnice. Dotyczy to także znaczenia poszczególnych cech w procesie identyfikacji (np. zachowanie pisarskiej ciągłości jest przy ocenie podpisów na dokumentach dość istotne; w przypadku sygnatur, ze względu na nietypowe narzędzia pisarskie oraz materiał kryjący, brak swobody przy kreśleniu sygnatury nie musi sugerować, że jest ona nieautentyczna) ${ }^{37}$.

Podobnie jak w przypadku podpisów, w badaniach sygnatur bardzo istotne jest dostarczenie odpowiedniego materiału porównawczego. Przede wszystkim nie powinno być żadnych wątpliwości co do jego autentyczności, powinien pochodzić z tego samego okresu co materiał kwestionowany oraz być sporządzony tym samym środkiem pisarskim ${ }^{38}$.

Sygnatura, podobnie jak tradycyjny podpis, ma wartość identyfikacyjną ze względu na występujący w niej zespół cech charakterystycznych dla wykonawcy. Dlatego im jest krótsza, tym trudniej o wydanie kategorycznej opinii co do jej pochodzenia. Na przykład sygnatury w postaci monogramów, kreślone zwykle w wolnym tempie i przy niezróżnicowanym nacisku, reprezentują niewielką ilość unikatowych cech pisma. Ich wartość identyfikacyjna jest niewielka, ponieważ ich naśladowanie jest dla fałszerza łatwym zadaniem ${ }^{39}$.

\footnotetext{
32 M. Morka, op. cit., s. 265.

33 D. Markowski, op. cit., s. 256.
}

34 Pod względem treściowym współczesne sygnatury prezentują różnorodny katalog. Więcej na ten temat: T. Widła, Treść sygnatury, w: J. Wójcikiewicz, V. Kwiatkowska-Wójcikiewicz (red.), Paradygmaty kryminalistyki, Wydawnictwo Uniwersytetu Jagiellońskiego, Kraków 2016, s. 211-220; T. Widła, Sfałszowane sygnatury, w: M. Trzciński, O. Jakubowski (red.), Przestępczość przeciwko dziedzictwu kulturowemu. Diagnoza, zapobieganie, zwalczanie, Katedra Kryminalistyki Wydział Prawa, Administracji i Ekonomii Uniwersytetu Wrocławskiego, Wrocław 2016, s. 221-233.

35 T. Widła, Treść..., s. 212-219.

36 D. Markowski, A. Koziczak, Falsyfikat na polskim rynku dzieł sztuki; znaczenie sygnatury w wartościowaniu dzieła sztuki, w: A. Jagielska-Burduk, W. Szafrański (red.), Kultura w praktyce. Zagadnienia prawne, t. 2: Wokół problematyki prawnej zabytków i rynku sztuki, Wydawnictwo Poznańskiego Towarzystwa Przyjaciół Nauk, Poznań 2013, s. 36.

37 Ibidem, s. 40.

38 T. Widła, Metody ustalania..., s. 274.

39 D. Markowski, A. Koziczak, op. cit., s. 40. 
Mistrz i uczniowie. Rola sygnatur w badaniach oryginalności... Master and students. The role of signatures in research of originality...

Podpis ewoluuje w procesie ontogenetycznym człowieka. Również podpis Rembrandta ulegał zmianom, jednak w ramach poszczególnych okresów jego twórczości sygnatury na obrazach charakteryzują się pewną stabilnością. Natomiast na akwafortach artysta eksperymentował z sygnaturami - na tych dziełach są one znacznie bardziej różnorodne ${ }^{40}$. Jako młody malarz Rembrandt podpisywał się jedynie monogramem „RH” (Rembrandt Harmenszoon - „syn Harmena”). Przykład może stanowić dzieło Operacja stopy. Ernst van Wetering wskazuje, że ten typ sygnatury występuje tylko na pracach powstałych między rokiem 1626 a 1629. Dodatkowo podkreśla, że litery są połączone poprzez wstęgę kończącą majuskułę „R”, umieszczoną na wysokości poprzeczki majuskuły „H”41. W późniejszym okresie artysta dodał do sygnatury literę L, którą autorzy identyfikują jak skrót od "Leidensis”, czyli nazwę miejscowości, z której pochodził. Monogram „RHL”, uzupełniony o datę powstania dzieła, widnieje m.in. na obrazie Symeon w świątyni z 1631 r. W 1632 r. Rembrandt sygnował dzieła „RHL van Rijn”. Następnie podpi-

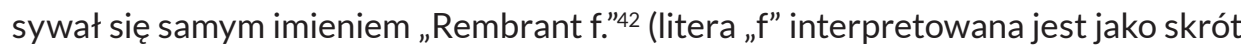
od łacińskiego słowa fecit - „wykonał”). Taka właśnie sygnatura widnieje na słynnej Lekcji anatomii dra Tulpa z 1632 r. Od 1633 r. mistrz podpisywał dzieła jedynie imieniem Rembrandt, zgodnie ze zwyczajem wielkich XV- oraz XVI-wiecznych artystów, np. Rafaela, Tycjana, Michała Anioła ${ }^{43}$. Poprawna ortograficznie pisownia imienia mistrza to Rembrant; litera "d" została dodana w sygnaturach występujących zarówno na obrazach, jak i oficjalnych dokumentach po $1633 r^{44}$

\section{Rembrandt Research Project}

W 1968 r. powołano Rembrandt Research Project (dalej: RRP), którego członkowie podjęli się trudnego zadania: głównym ich celem było opracowanie - za pomocą nowoczesnych technologii ${ }^{45}$ - nowego, kompleksowego zestawienia dzieł autorstwa Rembrandta, z wyłączeniem ogromnej liczby dzieł jego uczniów oraz naśladowców ${ }^{46}$. Naukowcy wnikliwie przeanalizowali technologię i techniki malarskie mistrza. Przeprowadzili również ekspertyzy fizykochemiczne oraz analizy sygnatur. Zadanie było tym trudniejsze, że najpierw badacze musieli wyodrębnić autentyczny podpis mistrza spośród podpisów widniejących na dziełach dotychczas

\footnotetext{
40 J. Bruyn et al., A selection of signatures 1632-1634, w: A Corpus of Rembrandt Paintings, t. II: 1631-1634, Martinus Nijhoff Publishers, Dordrecht - Boston - Lancaster 1986, s. 99, http://www.rembrandtdatabase. org/Rembrandt/Content/pdfs/CorpusRembrandt_2.pdf [dostęp: 5.09.2014].

41 E. van Wetering, An illustrated..., s. 161.

42 http://www.rembrandt-signature-file.com/remp_texte/remp050.pdf [dostęp: 5.09.2014].

43 E. van de Wetering, Rembrandt van Rijn...

44 http://www.rembrandt-signature-file.com/remp_texte/remp050.pdf [dostęp: 5.09.2014].

45 E. van de Wetering, Connoisseurship..., s. 83.

$46 \mathrm{http://rembrandtexperts.com/rembrandt-research-project.html} \mathrm{[dostęp:} \mathrm{26.08.2017].}$
} 


\section{DEBIUTY}

Marta Janocha

uznawanych za twórczość Rembrandta. Na podstawie testów naukowcy bardzo restrykcyjnie oceniali dzieła, odrzucając niekiedy atrybucje nawet bardzo znanych obrazów, np. Mężczyzny w złotym hełmie ${ }^{47}$. Analiza sygnatur Rembrandta pozwoliła na wyłączenie z katalogu dzieł holenderskiego mistrza wielu późniejszych kopii i fałszerstw, jednak badacze odkryli również, że zgodnie z XVII-wiecznym zwyczajem, autentyczne sygnatury mistrza widnieją na pracach jego uczniów.

Wyniki przeprowadzonych ekspertyz zostały przedstawione w pięciu publikacjach pod wspólnym tytułem A Corpus of Rembrandt Paintings ${ }^{48}$. W pierwszych trzech tomach publikacji A Corpus of Rembrandt Paintings podzielono dzieła Rembrandta powstałe do 1642 r. na trzy grupy w zależności od atrybucji:

A - dzieła namalowane przez mistrza,

B - dzieła prawdopodobnie namalowane przez mistrza,

C - dzieła z pewnością innego autora.

W tomie II dokonano przeglądu sygnatur na dziełach mistrza, z wykorzystaniem opinii specjalistów z Laboratorium Kryminalistycznego Ministerstwa Sprawiedliwości w Rijswijk. Niestety, w tomie tym brak zarówno szczegółowych informacji na temat wykorzystanego w badaniach materiału porównawczego, jak i opisu metody zastosowanej do wyłonienia autentycznych sygnatur mistrza spośród tysięcy podpisów zamieszczonych na XVII-wiecznych obrazach ${ }^{49}$. Wiadomo jedynie, że członkowie RRP konsultowali się z ekspertami pisma w formułowaniu własnych wniosków. Wyraźnie zaznaczono, że w wielu przypadkach ocena wiarygodności sygnatury została oparta w dużym stopniu na wrażeniu popartym wnioskami dotyczącymi jakości samego obrazu ${ }^{50}$.

Poza przypadkami występowania sygnatur Rembrandta na pracach jego uczniów, problemem okazały się także współczesne Rembrandtowi kopie z podpisem naniesionym przez kogoś innego. Rembrandt pozostaje największym malarzem holenderskiego złotego wieku, lecz otoczony był innymi znakomitymi twórcami ${ }^{51}$. Różnice w cenach uzyskiwanych za obrazy różnych artystów (przy niewielkich różnicach formalnych) powodowały, że nawet obrazy o dużej wartości estetycznej fałszywie sygnowano, by podbić ich cenę ${ }^{52}$. Przez wiele lat obraz pt. Mężczyzna w złotym hełmie był uznawany za jeden z najsłynniejszych portretów

47 E. van de Wetering, Connoisseurship..., s. 84.

48 Wraz z ukazaniem się ostatniego tomu w 2014 r. Tomy I-V są dostępne w Internecie: Springerlink oraz The Rembrandt Database, http://www.rembrandtdatabase.org.

49 W 2014 r. ukazał się jednak tom VI, który zgodnie z zapowiedzią wydawcy stanowi uzupełnienie informacji z poprzednich pięciu tomów oraz zawiera prezentację zastosowanej metodologii (http://www. springer.com/architecture+\%26+design/arts/book/978-94-017-9173-1 [dostęp: 15.12.2014]).

50 J. Bruyn et al., op. cit., s. 99.

51 R. Hughes, op. cit., s. 3.

52 M. Morka, op. cit., s. 253. 
Mistrz i uczniowie. Rola sygnatur w badaniach oryginalności... Master and students. The role of signatures in research of originality...

autorstwa Rembrandta ${ }^{53}$, jednak na podstawie analiz członkowie RRP przypisali to dzieło uczniowi mistrza - Johannowi Ulrichowi Mayrowi ${ }^{54}$.

\section{Polski akcent w działalności RRP}

W 1990 r. wydano III tom A Corpus of Rembrandt Paintings, dotyczący dzieł z lat 1635-1642, w którym nie uwzględniono jednak dwóch portretów z kolekcji Lanckorońskich: Uczony przy pulpicie (1641 r.) oraz Dziewczyna w kapeluszu (1641 r.). Dostęp do dwóch wspomnianych portretów był utrudniony, ponieważ stanowiły własność prywatną rodziny Lanckorońskich, pilnie strzeżoną w zaciszu szwajcarskiego banku. W 1994 r. prof. Karolina Lanckorońska przekazała rodzinny skarb zamkom królewskim w Warszawie i Krakowie. Po dokładnej analizie oryginałów kierownik RRP E. van de Wetering potwierdził autentyczność obrazów w lutym 2006 r. ${ }^{55}$ Holenderscy eksperci nie mieli natomiast żadnych wątpliwości co do atrybucji Krajobrazu z miłosiernym Samarytaninem z 1638 r.

Przywrócenie atrybucji „polskich Rembrandtów” było tematem ożywionych dyskusji, ponieważ ich kompozycja jest dla twórczości mistrza nietypowa (podczas gdy wiele obrazów o podobnej kompozycji występuje w twórczości utalentowanych uczniów Rembrandta - Ferdinanda Bola i Samuela van Hoogstratena). Rembrandt nie był jednak malarzem o utrwalonych nawykach - być może Dziewczyna w kapeluszu powstała jako prototyp przeznaczony do ćwiczeń dla młodych adeptów sztuki. Zastosowanie nietypowego drewna jako surowca (zarówno Uczony przy pulpicie, jak i Dziewczyna w kapeluszu zostały namalowane na topolowych deskach, raczej niestosowanych przez XVII-wiecznych malarzy) uprawdopodobnia fakt, że portrety pochodzą z warsztatu Rembrandta, gdyż w jego twórczości można odszukać 8 dzieł utworzonych na takich właśnie panelach ${ }^{56}$. Początkowo eksperci RRP przypisali autorstwo Dziewczyny w kapeluszu Samuelowi van Hoogstratenowi. Jednak według źródeł Hoogstraten urodził się w 1627 r. i mógł się pojawić w pracowni Rembrandta najwcześniej w 1642 r. lub na początku 1643 r. (ponadto E. van de Wetering określa wczesne obrazy Hoogstratena jako "raczej niezdarne" ${ }^{\text {57}}$ ). Z kolei polski historyk sztuki Antonii Ziemba przypisywał autorstwo Dziewczyny w kapeluszu Ferdinandowi Bolowi, który opuścił warsztat Rembrandta około 1641 r. Jednak po

\footnotetext{
$53 \mathrm{http://www.zamek-krolewski.pl/zwiedzanie/ekspozycje-stale/galeria-lanckoronskich-obrazy-}$ rembrandta.-galeria-malarstwa,-rzezby-i-sztuki-zdobniczej/rembrandt-research-project [dostęp: 15.12.2014].

54 T. Darowny, „lewa“ sygnatura czy żadna?, http://momart.org.pl/sprzedanewylicytowane-lewasygnatura-czy-zadna [dostęp: 15.12.2014].

55 http://www.zamek-krolewski.pl/zwiedzanie/ekspozycje-stale/galeria-lanckoronskich-obrazyrembrandta.-galeria-malarstwa,-rzezby-i-sztuki-zdobniczej/autorstwo-obrazow [dostęp: 6.09.2014].

56 E. van de Wetering, Connoisseurship..., s. 88.

57 Ibidem.
} 


\section{DEBIUTY}

Marta Janocha

przeprowadzeniu analiz przez RRP A. Ziemba zdystansował się do tej atrybucji58. Na zlecenie Zamku Królewskiego w Warszawie również Centralne Laboratorium Kryminalistyczne Komendy Głównej Policji przeprowadziło ekspertyzy sygnatur widniejących na obydwu dziełach ${ }^{59}$, uznając znajdujące się na nich sygnatury za autentyczne. Próbki farby pobrane z sygnatur przez Karin Groen (jednego z członków RRP) wskazują, że podpisy zostały złożone, zanim wyschła ostatnia warstwa dzieła ${ }^{60}$. Wiarygodna sygnatura świadczyła o pochodzeniu obrazów z warsztatu mistrza, a wnikliwa analiza pozostałych elementów pozwoliła na ostateczne wskazanie autora. Argumenty te przyczyniły się do ponownego uznania Dziewczyny w kapeluszu oraz Uczonego przy pulpicie za dzieła Rembrandta.

Zgodnie z poglądami zwolennika tradycyjnego sposobu określania atrybucji dzieł, Maxa Jacoba Friedländera, ekspert potrzebuje jedynie spojrzenia, by prawidłowo ocenić dzieło; jednak spośród jego intuicyjnych ekspertyz tylko około 50\% wytrzymało próbę czasu ${ }^{61}$. Jego zdaniem, doświadczony ekspert bez analizowania poszczególnych elementów dzieła rozpoznaje sposób pracy konkretnego artysty, w taki sam sposób jak ludzie rozpoznają inne osoby. Starsze pokolenia badaczy (włączając skład pierwszego RRP) stosowały tradycyjne sposoby ustalania autentyczności, oparte w dużym stopniu na intuicji i subiektywnych przesłankach (styl, praca pędzla, jakość) ${ }^{62}$.

W przypadku Rembrandta tradycyjna metoda jednak zawodzi, ponieważ holenderski malarz był artystą poszukującym nowych rozwiązań w sztuce. Z kolei wykorzystanie nowoczesnych technologii do określania atrybucji dzieł, proponowane początkowo w ramach RRP, nie pozwala na rozróżnienie pracy mistrza i pracy ucznia z tego samego warsztatu ${ }^{63}$. Nowe podejście w RRP opierało się więc na połączeniu studiów nad warsztatem artysty z wykorzystaniem zdobyczy współczesnej nauki, co przyczyniało się do głębszego poznania sposobu pracy artysty procesu tworzenia, rozwoju pomysłów konstrukcyjnych dzieł, operowania kontrastami ${ }^{64}$. Ostatecznie katalog dzieł Rembrandta zaprezentowany w VI tomie A Corpus of Rembrandt Paintings różni się znacząco od zaprezentowanego w poprzednich tomach. Ostatnia część A Corpus of Rembrandt Paintings zawiera wszystkie dzieła, co do których E. van de Wetering jest przekonany, że zostały namalowane przez

\footnotetext{
$58 \quad$ Ibidem, s. 89.

59 P. Rybicki, Techniczno-kryminalistyczne badania dzieł sztuki, w: J. Kaczmarek (red.), Prawnokarna ochrona dziedzictwa kultury, Zakamycze, Kraków 2006, s. 168.

60 E. van de Wetering, Connoisseurship..., s. 89.

61 Ibidem, s. 90.

62 E. van de Wetering, A Corpus of Rembrandt Paintings, t. VI: Rembrandt's Paintings Revised. Complete Survey, Springer Netherlands, 2015, s. 10.

63 E. van de Wetering, Connoisseurship..., s. 84.

64 E. van de Wetering, Content of the volume V Preface, w: A Corpus..., t. 5, s. IX.
} 
Mistrz i uczniowie. Rola sygnatur w badaniach oryginalności... Master and students. The role of signatures in research of originality...

Rembrandta lub że Rembrandt był przynajmniej ich współautorem ${ }^{65}$. Kierownik projektu zastrzega jednak, że sformułowanie opinii co do autentyczności dzieła stanowi trudne zadanie i w większości przypadków opiera się na subiektywnych kryteriach $^{66}$.

\section{Podsumowanie}

Powstające w XIX w. nowe galerie sztuki oraz coraz liczniejsze kolekcje prywatne na całym świecie wytworzyły ogromny popyt zarówno na dzieła sztuki współczesnej, jak i na obrazy dawnych mistrzów. Także proceder fałszowania obrazów rozwinął się na niespotykaną wcześniej skalę. Oprócz analizy pod względem technologii i technik malarskich, podstawą do potwierdzenia autentyczności dzieła stała się również analiza sygnatury. Proces starzenia się materiałów oraz skład pierwiastkowy farb to cechy niezwykle trudne do odtworzenia, dlatego naniesienie sygnatury na obraz innego, mniej znanego twórcy tego samego okresu stanowi dla fałszerza łatwiejszą metodę niż stworzenie współczesnej imitacji ${ }^{67}$. Jednak dosygnowanie obrazu, tak by nie wzbudzał podejrzeń kupującego, również jest skomplikowane, zwłaszcza że współcześnie uczestnicy rynku sztuki sięgają po opinie ekspertów z zakresu badań pisma. Przy ocenie autentyczności dzieła przypisywanego Claude'owi Monetowi - Am Seineufer bei Port Villez badacze zakwestionowali m.in. sygnaturę. Podrobione podpisy pomogły zdemaskować również fałszerstwo 8 rysunków Salvadora Dali68 oraz przyczyniły się do wyłączenia dzieła Rybak $z$ sieciq z twórczości Leona Wyczółkowskiego ${ }^{69}$. Znany jest także przykład procesu Luki Giordana, który własny obraz sygnował monogramem Albrechta Dürera ${ }^{70}$.

W podanych przykładach weryfikacja autentyczności nie była oparta wyłącznie na ekspertyzie sygnatury. Badanie takie nie może przesądzać o autentyczności dzieła w oderwaniu od wyników innych ekspertyz ${ }^{71}$. Należy pamiętać o praktyce sygnowania dzieł pochodzących z warsztatu wielkiego mistrza (jak to czynili

\footnotetext{
65 Ibidem, s. 9-10.

66 E. van de Wetering, A Corpus..., t. 6, s. 10, disclaimer.

67 M.Łuczak, Fałszerstwa dziełsztuki, wprowadzenie do problematykii współczesne zagrożenia, w: M. Trzciński, O. Jakubowski (red.), Przestępczość przeciwko dziedzictwu..., s. 191.

68 A. Jagielska, D. Markowski, Falsyfikat dzieła sztuki w wybranych orzeczeniach sadów polskich i niemieckich, „Acta Universitatis Nicolai Copernici, Zabytkoznawstwo i Konserwatorstwo" 2011, t. 41, s. 162.

69 Ekspertyza sygnatury została wykonana przez CLK KGP z wykorzystaniem metody graficznoporównawczej. Więcej na temat wyników badania w J. Piotrowska, Rybak z sieciq - prawdziwy czy fałszywy? Badanie sygnatur na obrazach jako metoda pomocnicza w ustalaniu autentyczności dzieła malarskiego, w: Problematyka autentyczności dzieł sztuki na polskim rynku. Teoria - praktyka - prawo, Narodowy Instytut Muzealnictwa i Ochrony Zbiorów, Warszawa 2012, s. 233-251.

70 P. Łada, Sygnowanie dzieł sztuki, 19.10.2011, http://rynekisztuka.pl/2011/10/19/sygnowanie-dzielsztuki/ [dostęp 28.10.2016].

71 M. Morka, op. cit., s. 257.
} 


\section{DEBIUTY}

Marta Janocha

Rubens, Corot, Ingres czy Rembrandt) ${ }^{72}$, a także o składaniu przez uznanych artystów autentycznych sygnatur na obrazach innych osób, np. Pablo Picasso podpisywał rysunki i obrazy, które uznał za satysfakcjonujące naśladownictwo własnego stylu ${ }^{73}$. O dużym znaczeniu sygnatury świadczy fakt, że sprzedawcy dzieł sztuki w opisach przedmiotu aukcji często podają adnotację o sygnowaniu obrazu, aczkolwiek coraz częściej czynią to w sposób umożliwiający uchylenie się od odpowiedzialności, jeżeli podpis lub obraz okażą się falsyfikatem ${ }^{74}$.

W ramach badań RRP analizowano sygnatury pod kątem zgodności brzmienia zapisu z okresem twórczości mistrza oraz podstawowych elementów konstrukcyjnych liter; badano podłoże i farbę w celu wykrycia symptomów ingerencji w podpis. W twórczości Rembrandta analiza sygnatury może posłużyć do ustalenia, czy dzieło pochodzi z najbliższego kręgu twórcy, stanowi współczesną Rembrandtowi kopię czy późniejsze fałszerstwo. Jednak dla odróżnienia pracy autorstwa samego mistrza i jego utalentowanego ucznia niezbędna jest wiedza eksperta - historyka sztuki. Sam podpis może być jedynie istotnym uzupełnieniem i potwierdzeniem wyników innych badań ${ }^{75}$. Sygnatura, bez względu na formę, stanowi użyteczne narzędzie identyfikacji twórcy, lecz z pewnością nie jedyne.

\section{Bibliografia}

Bruyn J., Haak B., Levie S.H., Thiel P.J.J. van, Wetering E. van de, A selection of signatures 1632-1634, w: A Corpus of Rembrandt Paintings, t. II: 1631-1634, Martinus Nijhoff Publishers, Dordrecht - Boston - Lancaster 1986, http://www.rembrandtdatabase.org/ Rembrandt/Content/pdfs/CorpusRembrandt_2.pdf [dostęp: 5.09.2014].

Burke P., Kultura i społeczeństwo w renesansowych Włoszech, przeł. K. Siewierski, Państwowy Instytut Wydawniczy, Warszawa 1991.

Darowny T., „lewa“ sygnatura czy żadna?, http://momart.org.pl/sprzedanewylicytowane-lewa-sygnatura-czy-zadna [dostęp: 15.12.2014].

http://rembrandtexperts.com/rembrandt-research-project.html [dostęp: 26.08.2017]

http://www.rembrandt-signature-file.com/remp_texte/remp050.pdf [dostęp: 5.09.2014].

http://www.zamek-krolewski.pl/zwiedzanie/ekspozycje-stale/galeria-lanckoronskich-obrazy-rembrandta.-galeria-malarstwa,-rzezby-i-sztuki-zdobniczej/rembrandt-research-project [dostęp: 15.12.2014].

http://www.zamek-krolewski.pl/zwiedzanie/ekspozycje-stale/galeria-lanckoronskich-obrazy-rembrandta.-galeria-malarstwa,-rzezby-i-sztuki-zdobniczej/autorstwo-obrazow [dostęp: 6.09.2014].

https://www.youtube.com/watch?v=4Y4GAq_hayY [dostęp: 5.09.2014].

72 P. Łada, op. cit.

73 D. Markowski, A. Koziczak, op. cit., s. 34.

74 M. Łuczak, op. cit., s. 187. Autor podaje przykładowe sformułowania: „obraz sygnowany przez...” lub „na obrazie widnieje sygnatura...”.

75 M. Morka, op. cit., s. 266. 
Mistrz i uczniowie. Rola sygnatur w badaniach oryginalności... Master and students. The role of signatures in research of originality...

Hughes R., Really Rembrandt?, „Time” 1992, t. 139, nr 21.

Jagielska A., Markowski D., Falsyfikat dzieła sztuki w wybranych orzeczeniach sadów polskich i niemieckich, „Acta Universitatis Nicolai Copernici, Zabytkoznawstwo i Konserwatorstwo" 2011, t. 41.

Łada P., Sygnowanie dzieł sztuki, 19.10.2011, http://rynekisztuka.pl/2011/10/19/sygnowanie-dziel-sztuki/ [dostęp 28.10.2016].

Łuczak M., Fałszerstwa dzieł sztuki, wprowadzenie do problematyki i współczesne zagrożenia, w: M. Trzciński, O. Jakubowski (red.), Przestępczość przeciwko dziedzictwu kulturowemu. Diagnoza, zapobieganie, zwalczanie, Katedra Kryminalistyki Wydział Prawa, Administracji i Ekonomii Uniwersytetu Wrocławskiego, Wrocław 2016.

Markowski D., Koziczak A., Falsyfikat na polskim rynku dzieł sztuki; znaczenie sygnatury w wartościowaniu dzieła sztuki, w: A. Jagielska-Burduk, W. Szafrański (red.), Kultura w praktyce. Zagadnienia prawne, t. 2: Wokół problematyki prawnej zabytków i rynku sztuki, Wydawnictwo Poznańskiego Towarzystwa Przyjaciół Nauk, Poznań 2013.

Markowski D., Ocena autentyczności dzieła na przykładzie wybranych obrazów polskiego malarstwa XIX i XX wieku, w: J. Flik (red.), Ars longa - Vita brevis. Tradycyjne i nowoczesne metody badania dzieł sztuki, Wydawnictwo Uniwersytetu Mikołaja Kopernika, Toruń 2003.

Michel E., Harmensz van Rijn Rembrandt, Parkstone International, New York 2011,.

Morka M., Kilka uwag o wartości sygnatur i pisaniu ekspertyz, w: J. Miziołek, M. Morka (red.), Falsyfikaty dzieł sztuki w zbiorach polskich, Agencja Wydawniczo-Poligraficzna Agraf, Warszawa 2002.

Piotrowska J., Rybak z sieciq - prawdziwy czy fałszywy? Badanie sygnatur na obrazach jako metoda pomocnicza w ustalaniu autentyczności dzieła malarskiego, w: Problematyka autentyczności dzieł sztuki na polskim rynku. Teoria - praktyka - prawo, Narodowy Instytut Muzealnictwa i Ochrony Zbiorów, Warszawa 2012.

Rybicki P., Techniczno-kryminalistyczne badania dzieł sztuki, w: J. Kaczmarek (red.), Prawnokarna ochrona dziedzictwa kultury, Zakamycze, Kraków 2006.

Starcky E., Rembrandt, przet. A. Kaniewska, „Panda”, Warszawa 1996.

Wetering E. van de, A Corpus of Rembrandt Paintings, t. 6: Rembrandt's Paintings Revised. Complete Survey, Springer Netherlands, 2015.

Wetering E. van de, An illustrated chronological survey of Rembrandt's small-scale 'histories': paintings, etchings and a selection of drawings, w: A Corpus of Rembrandt Paintings, t. V: Small scale history paintings, Springer Netherlands, 2011, http://www.rembrandtdatabase. org/Rembrandt/Content/pdfs/CorpusRembrandt_5.pdf [dostęp: 20.10.2016].

Wetering E. van de, Connoisseurship and Rembrantd's paintings: new directions in the Rembrandt's Research Project, part II, „The Burlington Magazine” 2008, t. 150, nr 1259.

Wetering E. van de, Content of the volume V Preface, w: A Corpus of Rembrandt Paintings, t. V: Small scale history paintings, Springer Netherlands, 2011, http://www.rembrandtdatabase.org/Rembrandt/Content/pdfs/CorpusRembrandt_5.pdf [dostęp: 20.10.2016].

Wetering E. van de, More than one hand in paintings by Rembrandt, w: A Corpus of Rembrandt Paintings, t. V: Small scale history paintings, Springer Netherlands, 2011.

Wetering E. van de, Rembrandt van Rijn [hasło], w: Encyclopaedia Britannica, https://www. britannica.com/biography/Rembrandt-van-Rijn [dostęp:10.10.2016].

Widła T., Metody ustalania autentyczności obrazów, „Studia Kryminologiczne, Kryminalistyczne, penitencjarne" 1979, t. 10. 


\section{DEBIUTY}

Marta Janocha

Widła T., Sfałszowane sygnatury, w: M. Trzciński, O. Jakubowski (red.), Przestępczość przeciwko dziedzictwu kulturowemu. Diagnoza, zapobieganie, zwalczanie, Katedra Kryminalistyki Wydział Prawa, Administracji i Ekonomii Uniwersytetu Wrocławskiego, Wrocław 2016.

Widła T., Sygnatura w ekspertyzie pismoznawczej - pisarska ciągłość, „Człowiek i Dokumenty” 2014, t. 34.

Widła T., Treść sygnatury, w: J. Wójcikiewicz, V. Kwiatkowska-Wójcikiewicz (red.), Paradygmaty kryminalistyki, Wydawnictwo Uniwersytetu Jagiellońskiego, Kraków 2016.

ZabłockaS.,Sygnatury, a autentycznośćdzieła,5.07.2012,http://rynekisztuka.pl/2012/07/05/ sygnatury-a-autentycznosc-dziela/ [dostęp: 6.09.2014].

Zabulska K., Ryciny ze zbiorów Muzeum Narodowego w Gdańsku, w: B. Purc-Stępniak, K. Zabuska, G. Zinówko (oprac.), Rembrandt i krąg jego tradycji, Muzeum Okręgowe im. Leona Wyczółkowskiego, Bydgoszcz 2010.

Zuffi S., Rembrandt, Rzeczpospolita, Warszawa 2006, s. 81. 